\title{
KETERAMPILAN MENULIS KARYA ILMIAH UNGGULAN KEPALA SEKOLAH DAN GURU SEKOLAH DASAR DI LINGKUNGAN KECAMATAN CIBINONG
}

\author{
Supriatnoko', Hastuti Redyanita ${ }^{2}$ \\ 1'2Jurusan Akuntansi Politeknik Negeri Jakarta \\ Jalan Prof. Dr. G.A. Siwabessy Kampus UI Depok \\ supriatnoko@gmail.com, hastuti.redyanita@gmail.com
}

\begin{abstract}
The community service activities carried out are training activities in writing superior scientific works. This training is important because the demands of expertise and attention to the value of great benefits as the competence of a principal and elementary school teachers in addition to the ability and skills in teaching subjects so that the professionalism of a principals and teacher is also reflected in his ability to write superior scientific works. This training was held for 2 days (7-8 October 2019) in the Hall of the KLP Office Cibinong Sub-District, Bogor Regency, with 40 participants, the determination was determined based on the purposive sampling method, representing 10 Teacher Working Group Clusters in the Cibinong SubDistrict Environment. This training is indoor, meaning the activities are carried out in the hall. The delivery techniques uses lecture, question and answer, discussion, independent work, and structured assistance. Participants are guided and assisted to be able to produce a scientific work, in the form of papers or in the form of scientifric articles. From the results of this training activity $100 \%$ of the participants can produce a scientific work that he wrote independently.
\end{abstract}

Key words: skills, writing, scientific work, independent

\begin{abstract}
Abstrak
Kegiatan pengabdian kepada masyarakat yang dilaksanakan ini adalah kegiatan pelatihan menulis karya ilmiah unggulan. Pelatihan ini penting dilakukan karena tuntutan keahlian dan memperhatikan nilai manfaatnya yang besar sebagai kompetensi seorang kepala sekolah dan guru sekolah dasar di samping kemampuan dan keterampilannya dalam mengajar mata pelajaran sehingga profesionalitas seorang kepala sekolah dan guru tercermin pula dari kemampuannya dalam menulis karya ilmiah unggulan. Pelatihan ini dilaksanakan selama 2 hari (7-8 Oktober 2019) bertempat di Aula Kantor KLP kecamatan Cibinong Kabupaten Bogor, dengan peserta sebanyak 40 orang, penentuannya ditetapkan berdasarkan metode purposive sampling, mewakili 10 Gugus Kelompok Kerja Guru di Lingkungan Kecamatan Cibinong. Pelatihan ini bersifat indoor, artinya kegiatan dilaksanakan di dalam aula. Teknik penyampaiannya menggunakan teknik ceramah, tanyajawab, diskusi, kerja mandiri, dan pendampingan terstruktur. Peserta dibimbing dan didampingi untuk dapat menghasilkan sebuah karya ilmiah, baik berupa makalah maupun berupa artikel ilmiah. Dari hasil kegiatan pelatihan ini $100 \%$ peserta dapat menghasilkan sebuah karya ilmiah yang ditulisnya secara mandiri.
\end{abstract}

Kata kunci: keterampilan, menulis, karya ilmiah, mandiri

\section{Pendahuluan}

Kepala sekolah dan guru sekolah dasar baik yang mengajar di sekolah negeri maupun sekolah swasta dituntut untuk mampu melaksanakan penelitian tindakan kelas (PTK), mampu menyajikan hasil penelitian ke dalam laporan ilmiah, mampu menulis artikel dari hasil penelitiannya untuk diterbitkan oleh majalah 
jurnal ilmiah, dan mampu menulis karya ilmiah unggulan baik dari hasil penelitian maupun dari hasil pemikiran dan pengamatan. Kemampuankemampuan itu diperlukan untuk meningkatkan kompetensi kepala sekolah dan guru untuk melengkapi keahlian bidang studi dan mata pelajaran yang diampunya.

Ada beberapa faktor hasil observasi yang menjadi hambatan bagi kepala sekolah dan guru di dalam melaksanakan penelitian atau membuat karya ilmiah unggulan, di antaranya adalah:

1. Kepala sekolah dan guru dihadapkan pada rutinistas pekerjaan administratif di samping tugas utama di bidang pengajaran, yaitu mengajar, sehingga kesempatan untuk melaksanakan kegiatan menulis karya ilmiah unggulan kekurangan waktu.

2. Kepala sekolah dan guru kurang dapat memanfaatkan waktu untuk melaksanakan penelitian di waktu mengajar atau di waktu luangnya. Hal ini terjadi karena guru melaksanakan kegiatan mengajar tidak dibarengi dengan perencanaan untuk melaksanakan penelitian tindakan kelas terhadap materi-materi yang diajarkan dan terhadap daya serap siswanya. Belum memfungsikan diri sebagai pengamat dalam melaksanakan tugas mengajarnya, minimal terhadap bidang studi yang menjadi tugas pengajarannya.

3. Kepala sekolah dan guru belum terlatih untuk menuangkan ide atau pemikirannya ke dalam bentuk karangan berupa karya ilmiah unggulan.

4. Belum ditemukan adanya program pemerintah daerah yang direncanakan secara terstruktur dan terprogram sebagai program tahunan peningkatan kemampuan kepala sekolah dan guru menulis karya ilmiah unggulan.

Karya ilmiah dapat berbentuk skripsi, tesis, disertasi, makalah, artikel ilmiah, dan laporan penelitian. Skripsi adalah karya tulis ilmiah yang ditulis untuk memenuhi persyaratan kelulusan dari studi jenjang S-1. Tesis adalah karya ilmiah yang ditulis untuk memenuhi persyaratan kelulusan dari studi jenjang S-2. Disertasi adalah karya ilmiah yang ditulis untuk memenuhi persyaratan kelulusan dari studi jenjang S-3. Makalah adalah karya ilmiah yang ditulis untuk memenuhi tugas terstruktur yang diberikan oleh dosen atau pihak pemberi tugas atau inisiatif sendiri untuk disajikan dalam forum ilmiah. Artikel ilmiah adalah karya ilmiah yang dirancang untuk dimuat dalam jurnal atau buku kumpulan artikel ilmiah, bersumber dari hasil penelitian, hasil pemikiran dan kajian pustaka, atau hasil pengembangan proyek. Laporan penelitian adalah karya ilmiah yang berisi paparan tentang proses dan hasil yang diperoleh dari suatu kegiatan penelitian (Maimunah, 2007: 66-73).

Prioritas masalah yang dipecahkan adalah kemampuan menulis karya ilmiah unggulan. Atas dasar prioritas tersebut di atas, Tujuan program yang ingin dicapai adalah:

1. Memberikan pelatihan untuk meningkatkan pengetahuan, kemampuan dan keterampilan kepala sekolah dan guru, serta penambahan wawasan mengenai kemampuan menulis karya ilmiah unggulan.

2. Memberikan pelatihan kepada kepala sekolah dan guru yang berdampak pada terarahnya pembelajaran menulis peserta didik untuk menghasilkan kalimat yang terstruktur baik dan benar sesuai gagasan dan konteks komunikasinya.

3. Memberikan pelatihan kepada kepala sekolah guru dalam upaya menumbuhkan minat dan membiasakan untuk menulis karya ilmiah unggulan di sela-sela rutinitas pekerjaannya. Menulis sebagai kegiatan melahirkan pikiran atau perasaan (seperti mengarang, membuat surat) dengan tulisan (KBBI, 2018: 1785). Menulis merupakan proses menjadi, yang tidak berlangsung satu kali jadi; ia membutuhkan tahap berkelanjutan, yaitu membutuhkan keterampilan swasunting untuk memastikan tulisan itu tepat dan baik (Fawaid, 2016: 11).

4. Memberikan pelatihan kepada kepala sekolah dan guru dengan target, mampu memadukan ranah afektif dan psikomotor dengan kognitifnya sehingga kerangka teoritis dapat diaplikasikan pada aktifitas keterampilan menulis. Secara teoritis, ranah kognitif adalah kemampuan yang berhubungan dengan berpikir, mengetahui dan memecahkan masalah. Ranah afektif adalah kemampuan yang berhubungan dengan sikap, nilai, minat dan apresiasi. Menurut Bloom (dalam Kurniawan 2011: 15), ranah afektif yaitu merujuk pada hasil belajar yang berupa kepekaan rasa atau emosi. Hasil belajar ranah psikomotor adalah ranah yang berkaitan dengan keterampilan (skill) 
atau kemampuan bertindak setelah seseorang menerima pengalaman belajar tertentu.

Kemampuan menulis karya ilmiah unggulan berupa makalah dan artikel ilmiah merupakan salah satu persyaratan mengikuti lomba program kepala sekolah dan guru teladan berprestasi tahunan tingkat kabupaten/kota dan tingkat provinsi dan sebagai unggulannya diikutkan pada lomba kepala sekolah dan guru teladan berprestasi tingkat nasional. Oleh sebab itu, pelatihan ini sejalan dengan program pemerintah untuk memiliki kepala sekolah dan guru yang mampu menulis karya ilmiah unggulan sehingga profesionalitas kepala sekolah dan guru tercermin pula dari kemampuannya dalam menulis karya ilmiah unggulan.

\section{Metode Pengabdian}

Program yang dilaksanakan berupa pelatihan. Target pelaksanaan pelatihan ini berorientasi pada kepala sekolah dan guru sebagai input pelatihan yang diharapkan untuk memiliki kemampuan menulis karya ilmiah unggulan. Oleh karena itu, inputnya adalah kepala sekolah dan guru, proses dilaksanakan melalui kegiatan pelatihan, outputnya adalah pengetahuan dan keterampilan menulis, outcomenya adalah kepala sekolah dan guru mampu menulis karya ilmiah unggulan sesuai dengan bidang ilmu dan keahliannya, sehingga menghasilkan satu karya ilmiah berupa makalah atau artikel. Berikut disajikan diagram proses. Pelaksanaan pelatihan menulis karya ilmiah unggulan melalui penggunaan Metode Dalam Ruangan. Adapun teknik penyampaiannya menggunakan teknik ceramah, tanyajawab, diskusi, kerja mandiri, dan pendampingan terstruktur.

Pelatihan ini dilaksanakan selama 2 hari kerja, yaitu pada tanggal 7-8 Oktober 2019 bertempat di Aula Kantor Layanan Pendidikan (KLP) Kecamatan Cibinong Kabupaten Bogor, Jalan Kayu Manis Kelurahan Ciri Mekar Kecamatan Cibinong, dengan jadwal dari pukul 08.00- s.d 17.00 wib. Adapun peserta pelatihan adalah para Kepala Sekolah dan Guru-guru Sekolah Dasar di Lingkungan Kecamatan Cibinong, penentuannya ditetapkan berdasarkan metode purposive sampling, mewakili 10 Gugus Kelompok Kerja Guru di Lingkungan Kecamatan Cibinong.

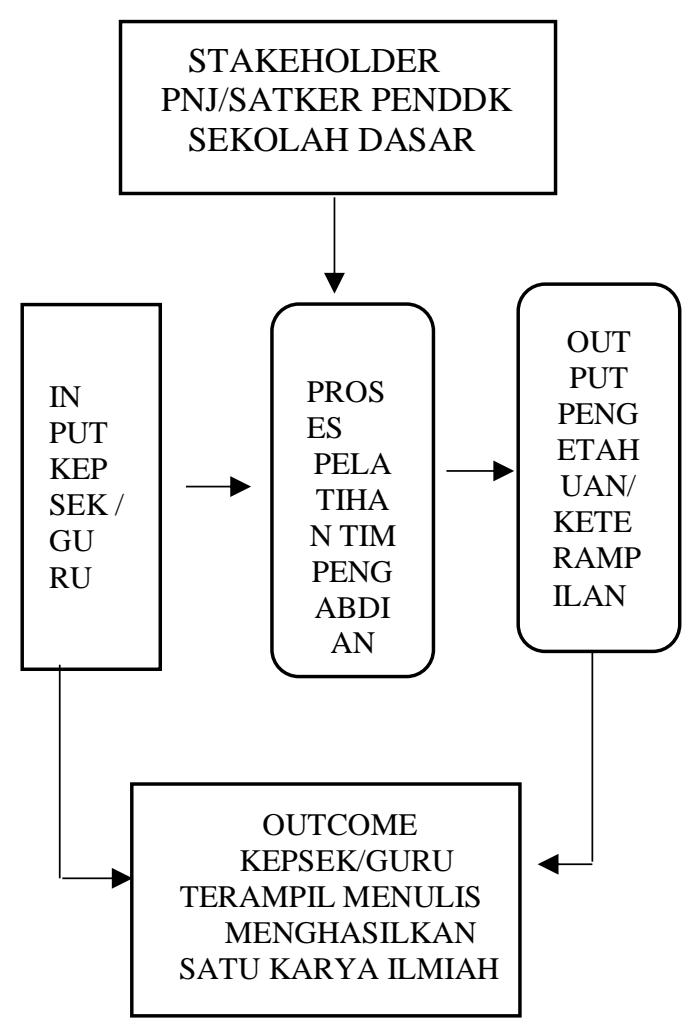

Diagram 1. Target Pelaksanaan Pelatihan Berorientasi Outcome

Mitra lembaga/institusi yang terlibat dalam program ini, adalah Kepala Kantor Layanan Pendidikan (KLP) Kecamatan Cibinong, digunakan tahapan-tahapan sebagai berikut:

1. Berkunjung ke Kantor KLP Kecamatan Cibinong untuk bertemu dengan Kepala KLP.

2. Perijinan, kepada Kepala KLP Kecamatan Cibinong Kabupaten Bogor sebagai Mitra Kerjasama.

3. Pengumpulan kebutuhan dan perencanaan konsep meliputi;

a. Pertemuan dengan Pihak KLP Kecamatan Cibinong Kabupaten Bogor bersama-sama menginventarisasi jumlah peserta yang mengikuti pelatihan.

b. Menginventarisasi calon peserta pelatihan dari kelompok kepala sekolah dan kelompok guru.

4. Menerima Surat Kesediaan Mitra Kerjasama dari Kepala KLP Kecamatan Cibinong Kabupaten Bogor.

5. Mitra membantu menyediakan aula pertemuan, mikrofon, infokus, dan konsumsi untuk peserta.

6. Mitra institusi berkontribusi pada perijinan pelaksanaan dan mengundang para kepala 
sekolah dan guru untuk mengikuti program pelatihan ini.

\section{Hasil dan Pembahasan}

Program berupa pelatihan dipilih atas dasar beberapa temuan faktor hambatan sebagaimana telah disebutkan pada bagian pendahuluan sehingga program ini dibutuhkan oleh kalangan kepala sekolah dan guru untuk mendapatkan pemahaman bagaimana menuangkan pikiran dan gagasan ke dalam wujud berupa karya ilmiah baik dari hasil penelitian maupun dari hasil pemikiran dan hasil observasi dari proses belajar mengajar di kelas. Deskripsi umum tentang program pelatihan ini, yaitu memberikan konsep dan teknik menulis karya ilmiah unggulan, memberikan pemahaman bagaimana memahami gagasan dalam menulis efektif, dan memberi pelatihan mandiri menulis karya ilmiah unggulan, bimbingan dan pendampingan, evaluasi dan monitoring.

Pelatihan menulis karya ilmiah unggulan ini dilaksanakan selama 2 hari pada tanggal 7-8 Oktober 2019. Pelatihan ini dihadiri oleh peserta sebanyak 40 orang, meliputi kepala sekolah dan guru serta dihadiri pula oleh Kepala KLP Kecamatan Cibinong.

Pelaksanaan pelatihan menulis karya ilmiah unggulan melalui penggunaan Metode Dalam Ruangan teknik penyampaiannya menggunakan teknik ceramah, tanyajawab, diskusi, kerja mandiri, dan pendampingan terstruktur. Adapun bekal materi yang disampaikan kepada peserta adalah:

1. Konsep dan teknik menulis karya ilmiah

2. Ejaan, tanda baca dan paragraf

3. Gagasan dan menulis efektif

4. Menulis karya ilmiah mandiri ter-bimbing

5. Pendampingan

6. Presentasi sampel hasil tulisan karya ilmiah peserta.

Tim Pelaksana kegiatan pelatihan ini adalah dosen Politeknik Negeri Jakarta dengan dibantu oleh 3 orang tenaga kependidikan, 1 orang pembantu umum, dan 3 orang mahasiswa Konsentrasi Penerjemahan Bahasa Inggris, sebagai aplikasi dari mata kuliah keterampilan menulis dan mata kuliah penulisan karya ilmiah.

Adapun indikator yang ditetapkan untuk pelaksanaan pelatihan ini diukur berupa indikator baseline (sebelum kegiatan pelatihan dilaksanakan) dan akhir kegiatan, yaitu sesudah kegiatan pelatihan dilaksanakan. Indikator target luaran dapat dilihat pada Tabel di bawah ini.

Tabel 1. Indikator Target Luaran

\begin{tabular}{|c|c|c|c|}
\hline $\mathrm{NO}$ & $\begin{array}{l}\text { INDIKATOR } \\
\text { TARGET } \\
\text { LUARAN } \\
\end{array}$ & SEBELUM & SESUDAH \\
\hline 1 & $\begin{array}{l}\text { Kesiapan kepala } \\
\text { sekolah dan } \\
\text { guru dalam } \\
\text { mengikuti } \\
\text { pelatihan } \\
\text { menulis karya } \\
\text { ilmiah unggulan }\end{array}$ & $0 \%$ & $100 \%$ \\
\hline 2 & $\begin{array}{l}\text { Pelaksanaan } \\
\text { serah terima } \\
\text { materi pelatihan }\end{array}$ & $0 \%$ & $100 \%$ \\
\hline 3 & $\begin{array}{l}\text { Pelaksanaan } \\
\text { Pelatihan }\end{array}$ & $0 \%$ & $100 \%$ \\
\hline 4 & $\begin{array}{l}\text { Pelaksanaan } \\
\text { Pendampingan, } \\
\text { monitoring dan } \\
\text { evaluasi }\end{array}$ & $0 \%$ & $100 \%$ \\
\hline 5 & $\begin{array}{lr}\text { Umpan balik } \\
\text { (feedback) dari } \\
\text { peserta } \\
\text { pelatihan }\end{array}$ & $0 \%$ & $100 \%$ \\
\hline 6 & $\begin{array}{l}\text { Karya ilmiah } \\
\text { peserta } \\
\text { pelatihan }\end{array}$ & $0 \%$ & $100 \%$ \\
\hline
\end{tabular}

Kegiatan pelatihan ini dilaksanakan selama 2 hari.

Hari pertama sesi pertama

Sesi pertama dimulai pada pukul 08.00 s.d. 12.00 wib.

Kegiatan pelatihan dibuka oleh pembawa acara dilanjutkan dengan sambutan ketua pelaksana kegiatan dan sambutan dari Kepala KLP Kecamatan Cibinong Kabupaten Bogor dan dilakukan foto bersama dan memulai kegiatan pelatihan. 


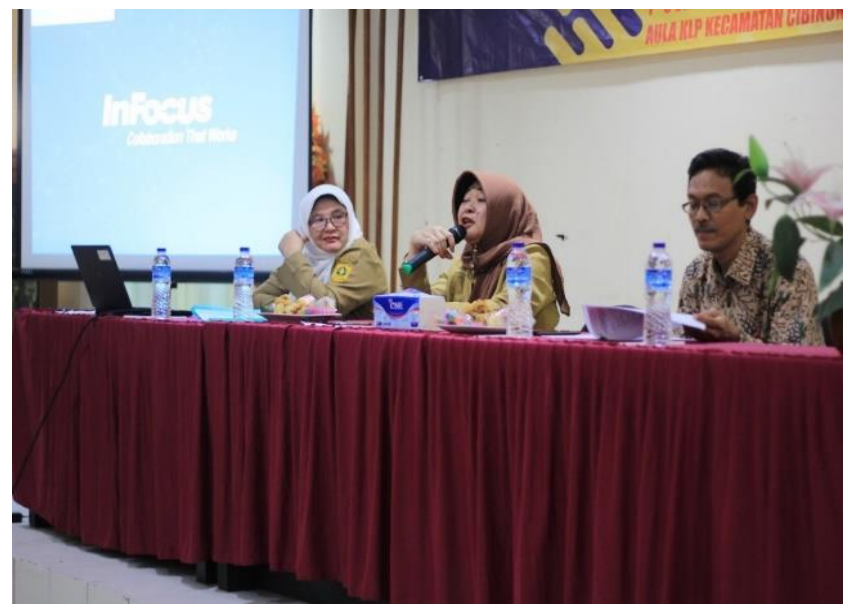

Kepala KLP Kecamatan Cibinong Memberikan Sambutan Pembukaan

Pada sesi peserta ini diberikan pemahaman konsep dan teknik menulis karya ilmiah, pemahaman ejaan, tanda baca dan paragraf, serta pemahaman gagasan dan menulis efektif. Temuan gagasan yang sebaiknya dituliskan pada bagian latar belakang untuk menghantarkan masalah, tujuan, kajian pustaka dan metode yang digunakan.

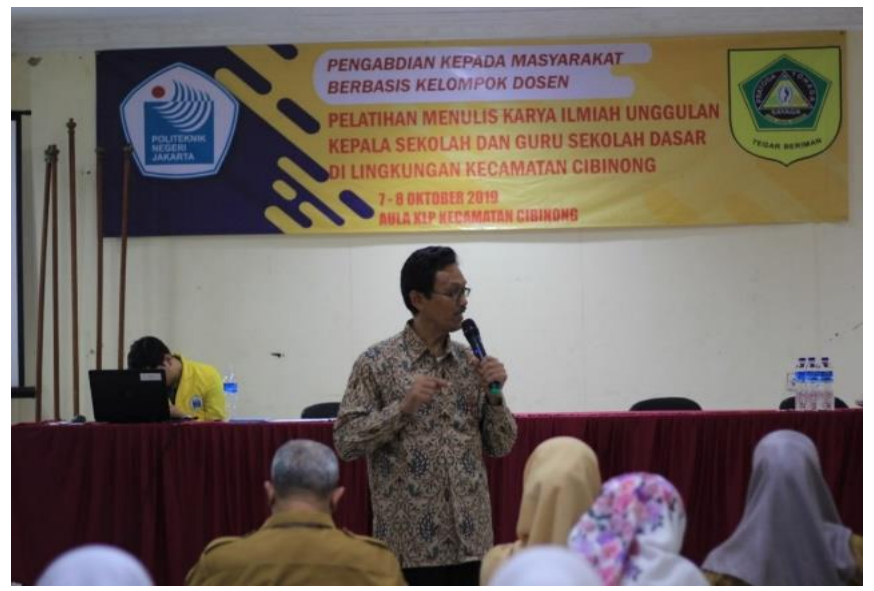

Narasumber Menyampaikan Pemaparan Materi Pelatihan

Peserta hadir dengan membawa laptop masingmasing untuk membantu kerja pembuatan karya ilmiah. Mereka antusias memperhatikan penjelasan dan pada sesi tanyajawab.

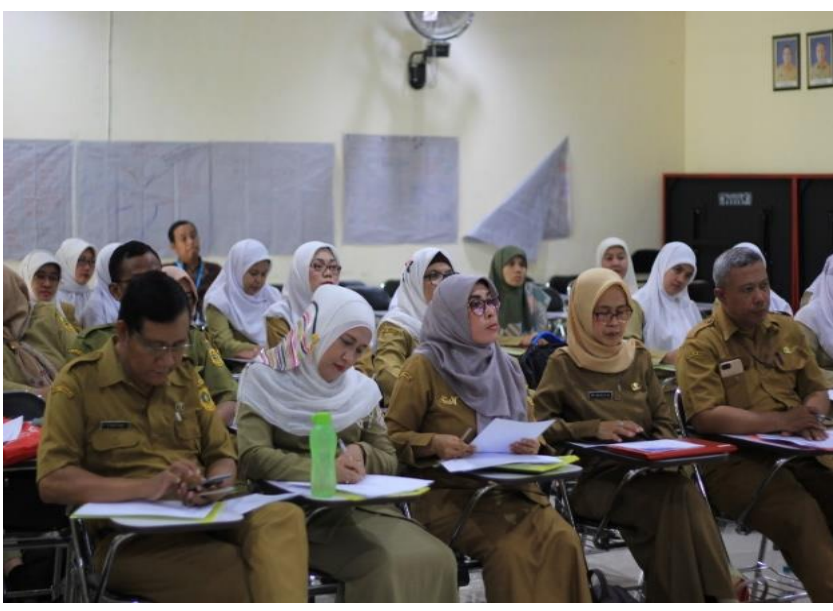

Peserta Antusias Menyimak Pemaparan

Banyak pertanyaan yang mereka sampaikan untuk memperkuat pemahaman mereka terhadap materi yang dipelajari. Hal ini menunjukkan bahwa mereka siap mengikuti dan menerima materi pelatihan.

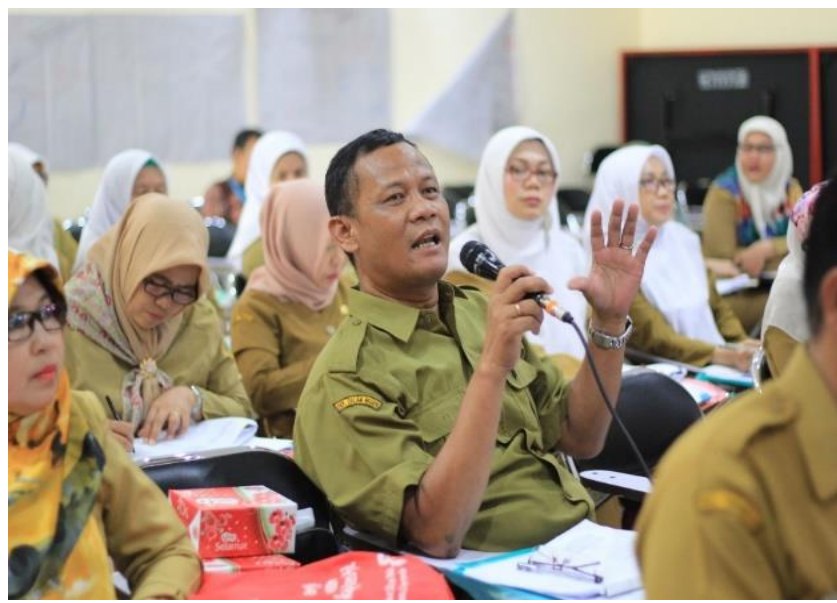

Peserta mengajukan Pertanyaan

Hari pertama sesi kedua.

Sesi kedua dimulai pada pkul 13.00 s.d. 17.00 wib. Peserta mulai menyiapkan secara mandiri topik karya ilmiah yang dibuat. Pada proses penulisan bagian pendahuluan ini, peserta diberi penjelasan bagaimana menemukan kerangka teori yang dapat mendukung makalah yang sedang ditulis, menuliskan sumber yang dijadikan kerangka teori pada bagian daftar pustaka/referensi serta menemukan metode dan teknik yang digunakan. Proses pendampinganpun mulai dilaksanakan selama peserta membuat karya ilmiah di hari pertama ini. 


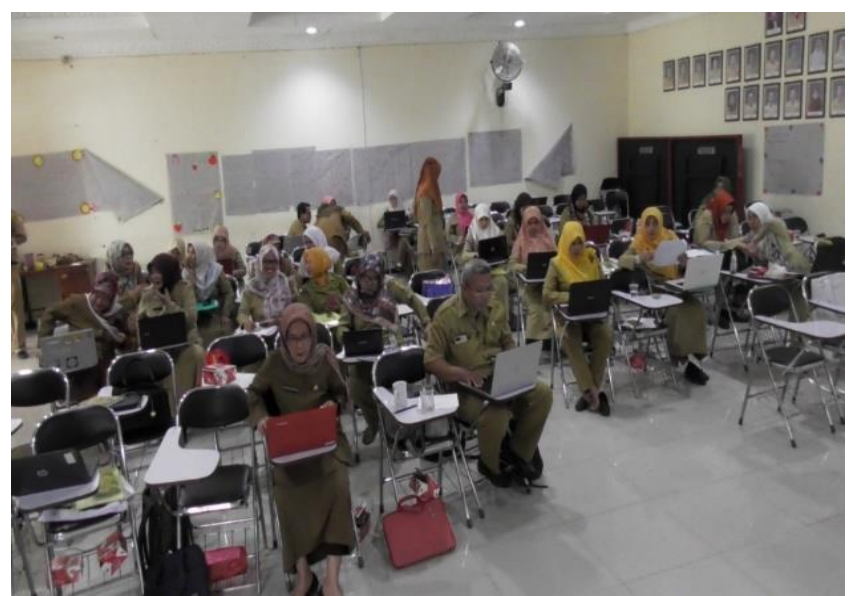

Peserta Serius Menyusun Karya Ilmiah Unggulan

Hari kedua sesi pertama

Peserta melanjutkan praktik penulisan karya ilmiah. Di hari kedua peserta secara mandiri melanjutkan penulisan karya ilmiah terbimbing sampai pada bagian hasil dan pembahasan. Tim pelaksana kegiatan melaksanakan pendampingan, monitoring dan evaluasi.

Hari kedua sesi kedua.

Sesi kedua, melanjutkan sesi pertama sampai terbentuk bagian pendahuluan sampai bagian kesimpulan dan daftar pustaka.

Di Akhir sesi kedua sebelum acara penutupan ditampilkan hasil penulisan karya ilmiah unggulan dari salah satu perwakilan peserta, didiskusikan dan dievaluasi secara bersama-sama serta diberikan umpan balik oleh Tim pelaksana. Dari proses pendampingan, monitoring dan evaluasi atas karya ilmiah yang telah ditulis, peserta telah mampu secara mandiri menyelesaikan tulisannya berupa makalah/artikel ilmiah. Langkah selanjutnya adalah proses penyempurnaan dan editing secara mandiri oleh masing-masing peserta untuk dapat digunakan sesuai keperluan mereka masing-masing. Peserta mendapat sertifikat pelatihan dari Politekik Negeri Jakarta.

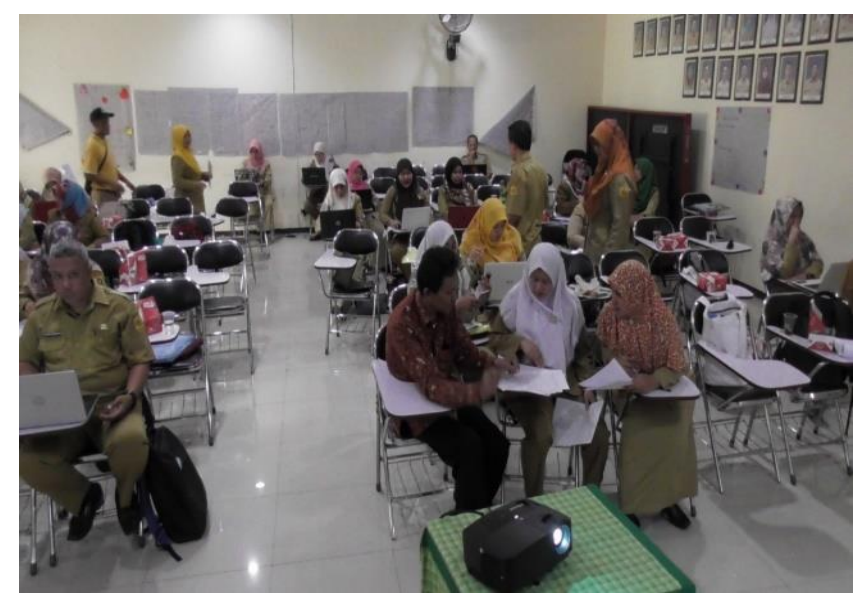

Narasumber Melaksanakan Pendampingan Monitoring dan Evaluasi

\section{Kesimpulan}

Kegiatan pelatihan menulis karya ilmiah unggulan dengan peserta kepala sekolah dan guruguru sekolah dasar di lingkungan Kecamatan Cibinong dapat dilaksanakan dengan tertib dan lancar. Peserta sangat antusias mengikuti pelatihan ini. Terbukti dari kehadiran mereka sejak hari pertama dan berakhir penutupan pada hari kedua, 40 peserta tetap dengan semangat menghadiri pelatihan ini.

Dari hasil kegiatan pelatihan ini $100 \%$ peserta dapat menyelesaikan karya ilmiah unggulan yang ditulisnya secara mandiri. Mereka merasa pelatihan dua hari ini belum cukup untuk menyelesaikan proses penyempurnaan dan editing dari karya ilmiah yang mereka buat secara mandiri sehingga tuntas diselesaikan selama waktu pelatihan. Di sisi lain, mereka mengusulkan agar pelatihan menulis karya ilmiah ini dapat dilaksanakan setiap tahun untuk para kepala sekolah dan guru. Mereka merasa terbantu karena materi pelatihan merupakan materi yang mereka harapkan untuk meningkatkan keterampilan serta menyegarkan kembali pemahaman mereka menulis karya ilmiah. Bagi Tim Pelaksanan, permintaan mereka merupakan peluang untuk dijadikan program binaan UP2M Politeknik Negeri Jakarta jika pimpinan dapat menyetujuinya sebagai kemungkinan pengembangan ke depan.

\section{Ucapan Terima Kasih}


Pada kesempatan ini penulis mengucapkan terima kasih kepada Kepala UP2M Politeknik Negeri Jakarta dan Kepala KLP Kecamatan Cibinong yang telah memberi dukungan terhadap keberhasilan kegiatan pengabdian ini serta Kepada Pimpinan Politeknik Negeri Jakarta yang telah menyediakan anggaran untuk pelaksanaannya.

\section{Daftar Pustaka}

[1] Siti Annijat Maimunah. 2007. Buku Pintar Bahasa Indonesia: untuk Pelajar, Mahasiswa, Dosen dan Umum. Jakarta: Penerbit Prestasi Pustakaraya.
[2] Badan Bahasa Kementerian Pendidikan dan Kebudayaan RI. 2018. Kamus Besar Bahasa Indonesia Edisi 5. Jakarta: Badan Bahasa.

[3] Achmad Fawaid. 2016. Pengantar Penulisan Akademik. Yogyakarta: Pustaka Pelajar.

[4] D. Kurniawan. 2011. Pembelajaran Terpadu. Bandung: Pustaka Cendikia Utama

[5] Zainal Arifin dan S. Amran Tasai. 2014. Cermat Berbahasa Indonesia untuk Perguruan Tinggi. Jakarta: Penerbit Akademika Pressindo.

[6] Badan Bahasa Kementerian Pendidikan dan Kebudayaan RI. 2016. Pedoman Umum Ejaan Bahasa Indonesia. Jakarta: Badan Bahasa. 